\title{
Five-axis CNC machine Tool based on UG Software for Automatic programming and Simulation of Complex Surface Impeller
}

\author{
Xiurong Zhu and Xin Zheng \\ School of Mechanical Engineering \\ Jilin Engineering Technology College \\ Changchun Jilin province of China \\ zxr67811@163.com
}

Keywords: Five-axis; CNC machine tools; Impeller; UG automatic programming; Simulation proce ssing

\begin{abstract}
This through the parametric optimization and simulation processing on the five-axis CNC machine tool with automatic programming of complex shapeparts, the complete machining technology and $\mathrm{NC}$ program are compiled. Automatic programming plays an important role in the machining of the impeller. In the five-coordinate machine tool blade surface profile, the root is the positioning and clamping of the reference plane, the top of the blade using thimble tight manner, thimble hole processing simple, reliable positioning, but the thimble hole relative to the reference plane position detection Difficulty, thimble holes are usually offset relative to the reference plane, in the processing of the blade body line must be 3D compensation.
\end{abstract}

\section{Introduction}

With the continuous development of science and technology, many foreign enterprises have taken a fancy to the rapid development of manufacturing in our country. We started to establish manufacturing plants on a large scale in our country and introduced advanced numerical control machine tools into production and processing, Developed by triaxial multi-axis. In this paper, the processing object of five-axis $\mathrm{CNC}$ machine tool is the research content. The importance of parameter setting in the process of automatic programming of five-axis CNC machine tools is analyzed in depth. The comparison between macro program and ordinary program, UGNX software programming is analyzed. The method of automatic compilation of complex parts of CNC machine tools is analyzed. The method of programming complex parts of CNC milling machine by automatic programming is analyzed. Analyzed the method that uses automatic programming.[1]

Through the research on the programming and machining of the five-axis CNC machine tool impeller, the programming and processing rules of the automatic programming of complex parts on a five-axis $\mathrm{CNC}$ machine tool are found out. For five-axis $\mathrm{CNC}$ lathe design programming library, NC programmers in the similar shape parts of the programming reference to the relevant procedures can be programmed to meet the actual shape of the program, improve production efficiency.[2]

In the use of automatic programming UG software programming convenience, less demanding on the programming staff, as long as the software and a small amount of CNC control expertise can be, the processing path is good, high precision machining. At this stage in the enterprise processing and CNC skills competition, are automatically programmed, the use of automatic programming has
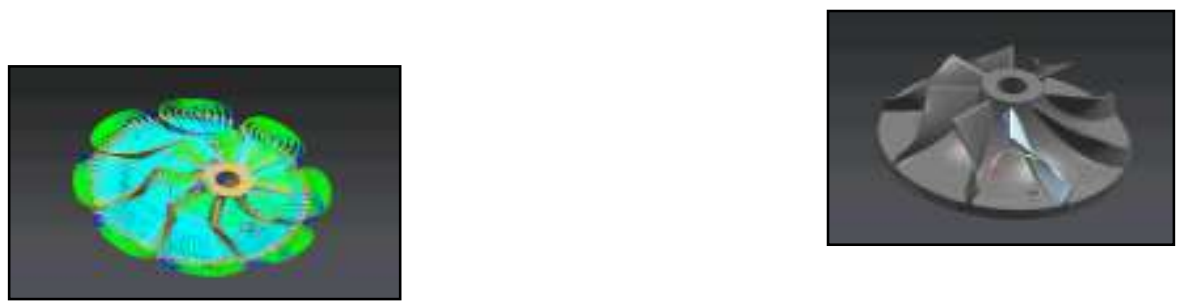

become a trend.

Figure 1. Impeller parts diagram

Figure 2. Impeller entity map 


\section{Analyze the Part Drawing and Determine the Installation Reference}

The parts are pictured, the part has curved surfaces, circular holes, negative angles and distortions associated with the blades, and the surface and seat frame require integration. Taking into account the structure and shape of the parts, as well as the actual processing of five-axis machine tool used in the processing characteristics, select the bottom part of the fixture for the positioning surface.[3]

Considering the parts of the length, width and height of the maximum size were $85 \mathrm{~mm}, 85 \mathrm{~mm}$, $35 \mathrm{~mm}$, so choose the blank size of $100 \mathrm{mmX100mmX40mm} \mathrm{cube.} \mathrm{Considering} \mathrm{the} \mathrm{machining} \mathrm{ability}$ requirements and rigidity of the CNC machine tool used, the surface roughness and the dimensional accuracy of the parts are all higher. Therefore, the material of the selected part is PVC because the cutting performance of the PVC is good and does not need to be done Heat treatment processing.

\section{To Determine the Processing Methods and Processing Routes}

Selection of Processing Methods, Parts of the surface and the cylindrical hole roughness requirements, so in milling, you can call the first rough milling, then fine milling program. Also consider the selected parts of the rough is PVC, the cutting performance is good and the surface without crust, so the use of milling in the next milling method, which can increase the surface roughness of its processing parts and can reduce tool wear. In the surface and blade processing, taking into account the accuracy of the machine tool processing and positioning accuracy, you can use the ball milling cutter, roughing and finishing milling, we can meet the requirements of parts machining accuracy.[4]

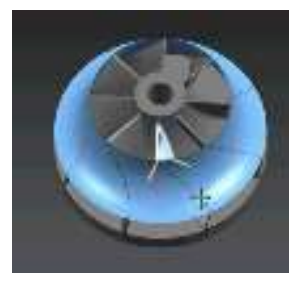

Figure 3. Leaf orientation

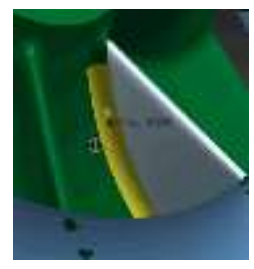

Figure 4. Edge blank analysis point

Choose the Processing Route, In determining the processing route, we should follow the principle that "the base surface before the first back hole, the first rough fine" in the outer contour of the impeller processing, due to the rough is PVC, good cutting performance, it should be Using down milling processing methods for processing, in order to improve the quality of its processing. At the same time, when cutting and cutting the tool, in order to avoid cutting and cutting in the tool to leave the knife feed and retract marks, so the tool should be tangential along the part cut and tangential cut.[5]

Therefore, according to the characteristics of the rough, in the processing, select the bottom as the positioning datum, the first in order of rough milling impeller surface, and then fine milling impeller of the various curved surface, and then roughing, finishing round hole The inner contour, and then the workpiece angle of the corresponding processing until all the blade processing until the last part of the surface processing, taking into account the integration of parts so need to create a dedicated fixture to ensure the positioning accuracy of the workpiece.[6]

Choose the Amount of Cutting, As the parts of the rough selection of PVC, so the cutting of processing performance is good, the processing machine used is a five-axis CNC machining machine, taking into account the actual use of vertical machining center performance and processing characteristics, the back to eat the amount of knife The maximum value of $2 \mathrm{~mm}$, but also because the machined parts of the surface roughness is higher, so the need for roughing, finishing, so roughing, the choice of the back to eat knife MID is $1.0 \mathrm{~mm}$, fine The finishing allowance selected for machining is $0.1 \mathrm{~mm}$. In addition, since the feed rate of the machine tool is $100 \mathrm{~mm} / \mathrm{min}$, in order to improve the machining efficiency, the feed rate in the profile direction (ie, FFP1) is selected to be $100 \mathrm{~mm} / \mathrm{min}$ in the roughing process and the feed amount in the depth 
direction 50mm / min. In finishing, the feed for the profile direction (ie FFP1) is selected to be 80 $\mathrm{mm} / \mathrm{min}$ and the feed to the depth (ie FFD) to $40 \mathrm{~mm} / \mathrm{min}$ for surface and contour machining accuracy.[7][8]

As the processing of parts material is PVC, the cutting performance, and the selected feed and back to eat the amount of knife are relatively small, so the inspection table reference, the cutting speed can be made larger, so the choice of cutting speed $160 \mathrm{~m} / \mathrm{min}$. Therefore, when you choose to? Milling milling parts milling, the spindle speed: After calculation available, you can choose the roughing spindle speed $6000 \mathrm{r} / \mathrm{min}$, finishing the spindle speed 6000r / $\mathrm{min}$. [9]

The choice of cutting three elements shown in Table 1:

Table 1 Cutting three elements

\begin{tabular}{|l|l|l|l|l|l|}
\hline $\begin{array}{l}\text { Product } \\
\text { name or } \\
\text { code } \\
\text { name }\end{array}$ & Part name & & $\begin{array}{l}\text { Part drawing } \\
\text { number }\end{array}$ & \\
\hline $\begin{array}{l}\text { Serial } \\
\text { number }\end{array}$ & $\begin{array}{l}\text { Too } \\
\text { num } \\
\text { ber }\end{array}$ & $\begin{array}{l}\text { Tool } \\
\text { specificatio } \\
\text { n and name }\end{array}$ & $\begin{array}{l}\mathrm{N} \\
\mathrm{U}\end{array}$ & $\begin{array}{l}\text { Machined } \\
\text { surface }\end{array}$ & $\begin{array}{l}\text { Re } \\
\text { ma } \\
\text { rks }\end{array}$ \\
\hline 1 & T01 & $\begin{array}{l}\varphi 50 \quad \text { Face } \\
\text { milling } \\
\text { cutter }\end{array}$ & 1 & $\begin{array}{l}\text { Rough } \\
\text { finishing of } \\
\text { the upper } \\
\text { surface of a } \\
\text { part }\end{array}$ & \\
\hline 2 & T02 & $\varphi 4$ butt mill & 2 & $\begin{array}{l}\text { The rough } \\
\text { outline of } \\
\text { the hole }\end{array}$ & \\
\hline 3 & T03 & Ф2 butt mill & 2 & $\begin{array}{l}\text { Surface } \\
\text { finishing } \\
\text { rough } \\
\text { finishing }\end{array}$ & \\
\hline 4 & T04 & $\Phi 1$ butt mill & 2 & $\begin{array}{l}\text { Finishing of } \\
\text { the blade }\end{array}$ \\
\hline
\end{tabular}

Table 2 NC cutting tool card

\begin{tabular}{|c|c|c|c|c|}
\hline & \multirow{2}{*}{$\begin{array}{l}\text { speed } \\
\text { of } \\
\text { mains } \\
\text { haft } \\
(\mathrm{r} / \mathrm{min} \\
\text { ) }\end{array}$} & \multicolumn{2}{|c|}{$\begin{array}{l}\text { Feed } \\
\text { rate } \\
(\mathrm{mm} / \mathrm{min})\end{array}$} & \multirow{2}{*}{$\begin{array}{l}\text { The } \\
\text { cuttin } \\
\mathrm{g} \\
\text { depth } \\
(\mathrm{mm})\end{array}$} \\
\hline & & $\begin{array}{l}\text { FA } \\
\mathrm{L}\end{array}$ & $\begin{array}{l}\text { FA } \\
\text { LD }\end{array}$ & \\
\hline $\begin{array}{l}\text { Rough } \\
\text { cutting }\end{array}$ & 6000 & 100 & 50 & 1.0 \\
\hline $\begin{array}{l}\text { fine } \\
\text { machini } \\
\text { ng }\end{array}$ & 6000 & 80 & 40 & 0.1 \\
\hline
\end{tabular}

Select the Tool, Milling the surface of the work piece, the use of face milling cutter, in order to improve the accuracy of surface machining parts to avoid knives in the knives produced at the 
junction, so the choice of the tool diameter should be as large as possible, so milling the surface of the workpiece When the choice of face cutter diameter $50 \mathrm{~mm}$. When milling a square profile, the diameter of the selected end mill is $4 \mathrm{~mm}$ for milling the inner profile due to the spherical profile limitation (spherical radius $30 \mathrm{~mm}$ ). Finishing spherical profile, the choice of diameter $2 \mathrm{~mm}$ ball milling cutter for processing. In the processing of text and graphics, you can choose the diameter of $1 \mathrm{~mm}$ ball milling cutter for milling. The tool material is carbide, good rigidity, to meet the processing stiffness requirements. See CNC tool card.[10]

Parts CNC machining tool card as follows:

UG Automatic Programming and Simulation Processing

Process 1 Rough Milling Outline Roughing Process

N0010 G40 G17 G90 G71;

N0020 T00 M06;

N0030 G00 X-42.044 Y1.629 A0.0 C0.0 S10000 M03;

N0040 G43 Z96.292 H00;

......

N4380 G01 X-44.;

N4390 Z59.792;

N4400 G00 Z96.292;

N4410 M30;

Ball head finishing process

N0010 G40 G17 G90 G71;

N0020 T00 M06;

N0030 G00 X-42.044 Y1.629 A0.0 C0.0 S10000 M03;

N0040 G43 Z96.292 H00;

......

N4380 G01 X-44.;

N4390 Z59.792;

N4400 G00 Z96.292;

N4410 M30;

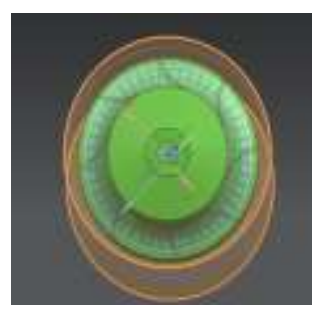

Figure 5. Rough contour simulation

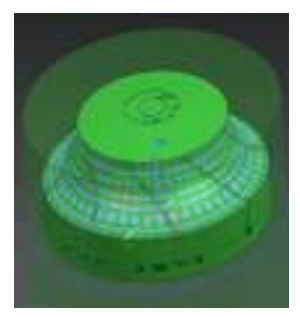

Figure6. Semi-finishing simulation

\section{Process semi-finishing Program}

\section{Concluding Remarks}

Through the research on UG generation program, a complex shape processing program with the advantage of automatic programming is summarized on a five-axis CNC machine tool. Taking complex parts as an example, a complete machining technology and NC program are compiled, and automatic programming is performed on the machining of the impeller Plays an important role. Through the study of this paper, the CNC machining staff realize the importance of automatic programming and the necessity of using automatic programming skillfully. 
In this paper, five-axis $\mathrm{CNC}$ machine tools for complex parts of the automatic programming design and implementation of NC programming for complex parts of the automatic programming has a reference value.

\section{References}

[1] Guangzhen, Lu Jianxiang, NC technology and programming [M]. Beijing: Peking University press, 2015.08

[2] Meng Lingxia, Zhang Zhi, numerical control technology training course [M]. Beijing: National Defence Industry Press, 2014

[3] Peng L. Individual Vision and Peak Distribution in Collective Actions [J]. Communications in Nonlinear Science and Numerical Simulation. 2017, 47: 238-252.

[4] Tang Wenxian, introduction and improvement of CNC machining process [M]. Beijing: China Machine Press, 2013

[5] Wu Zhiguo, Huang Yunlin, and so on, CNC lathe programming 80 cases: the essence of the [M]. Beijing: Chemical Industry Press, 2014 (in Chinese)

[6] Lv Binjie, Gao Changyin, Zhao Wen (FANUC.SIEMENS), CNC lathe programming example of the essence of [M]. Beijing: Chemical Industry Press, 2011

[7] Ni Xiangming, CNC machine tools and CNC machining technology [M]. people's Posts and Telecommunications Press, 2011

[8] Sun Xingwei, Xue Xiaolan, FANUC programming and processing of CNC machine tools [M]. Beijing: China Water Conservancy and Hydropower Press, 2015 (in Chinese)

[9] Yunjie Zhang、 Lijian Hao, CATIA V5-6 R2014 foundation design case. Tsinghua University Press, 2015.06

[10] Yunjie Zhang, Yunjing Zhang, CATIA V5 from to master. Tsinghua University Press, 2013,R21, entry, the

[11]Zhan Yi, CATIA V5R20 CNC machining tutorial [M]. Beijing: China Machine Press, 2013 